\title{
Preparation and Evaluation of Next-Generation Ni Multilayer Ceramic Chip Capacitor Electrode Using Ni Flake Powder
}

\author{
Ryosuke UEYAMA, Tomohiro ANDO, Taro MORIMITSU* and Yoshiki HASHIZUME*
}

Engineering 2 Department, Electronic Material Division, Daiken Chemical Co., Ltd., 2-7-19, Hanaten-nishi, Joto-ku, Osaka-shi 536-0011

*Powder and Paste Group, Research and Development Department, Core Technology Center, Toyo Aluminum K. K.,

4-1, Aioi-cho, Yao-shi, Osaka 581-0082

\section{$\mathrm{Ni}$ フレーク粉を用いた次世代 Ni-MLCC 電極の作製と評価}

\author{
上山竜祐·安藤智公 · 森光太郎* ·橋詰良樹*
}

大研化学工業(株)電子材料事業部技術 2 部， 536-0011 大阪市城東区放出西 2-7-19

*東洋アルミニウム (株) コアテクノロジーセンター研究開発室パウダー・ペーストグループ， 581-0082 大阪府八尾市相生町 4-1

\begin{abstract}
Flake-type Ni powder was studied to enable further thinning of the MLCC Ni electrode. Considering the manufacturing process for the present ceramic capacitor, it is necessary to make the firing shrinkage action of what similar to that of a dielectric green sheet. Nickel flake paste with added organometallic acid salt of the same composition as nickel flake powder and ceramics was considered. According to the results of our study, the sintering of electrode paste films is inhibited when using Ni flake paste with an organometallic acid salt in contrast to using Ni spherical paste. A similar result has been obtained by observing of the surface structure of sintered bodies.

[Received August 29, 2006; Accepted November 16, 2006]
\end{abstract}

Key-words : Ni flake powder, $M L C C$, Ni electrode

1. Introduction

The miniaturization of multilayer ceramic chip capacitors (MLCCs) with a larger capacitance has been advancing yearly. Capacitance is directly proportional to the dielectric constant and number of layers of a dielectric, and inversely proportional to the thickness of a dielectric layer.

Therefore, to achieve small capacitors with a large capacitance, it is necessary not only to increase the dielectric constant and number of layers of a dielectric material and decrease the thickness of a dielectric layer, but also to decrease the thickness of an electrode layer.

To realize a much thinner electrode film, which is essential for obtaining smaller MLCCs, a smaller Ni powder particle size is necessary. The minimum particle size of Ni powder is currently $0.2 \mu \mathrm{m}$. We have reported the characteristics of electrode paste made of $0.2 \mu \mathrm{m}$ particle size spherical Ni powder and the MLCC characteristics. ${ }^{1}{ }^{12}$ In aiming at the realization of a much thinner electrode film, we adopted the Ni electrode films shown in Fig. 1. It is considered that the thickness of an electrode film can be further reduced using flaky Ni powder (Ni flake powder, hereafter) instead of conventional spherical Ni powder.

Therefore, in this study, to realize a much thinner electrode film, we first examine the characteristics of electrode paste aiming at using Ni flake powder as an internal electrode of MLCCs. Second, we evaluate the capacitance characteristics of the MLCC fabricated using Ni flake powder and experimentally examine the applicability of $\mathrm{Ni}$ flake paste as an internal electrode of MLCCs.

\section{Experimental methods}

2.1 Preparation and evaluation of electrode paste

In this study, we used $\mathrm{Ni}$ flake powder, the SEM image and particle size distribution of which are shown in Fig. 2. The aspect ratio of $\mathrm{Ni}$ flake powder was 20.7.

As a sintering suppressor $\mathrm{BaTiO}_{3}$ resinate containing 20

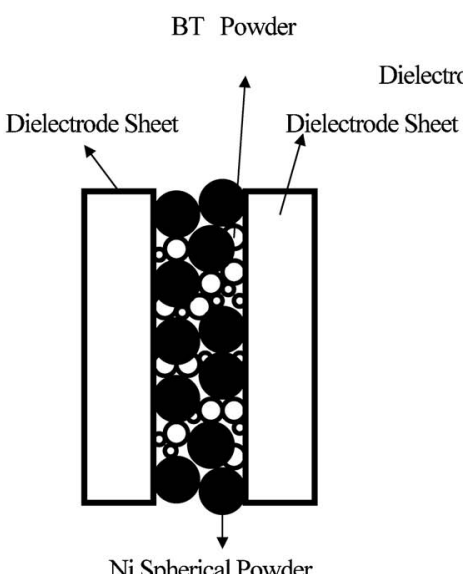

(a)
BT Resinate

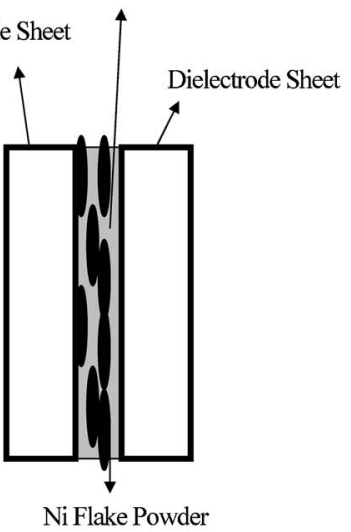

(b)
Fig. 1. Typical model of Ni electrodes. (a) Cross-sectional view of conventional electrode using spherical Ni powder and $\mathrm{BaTiO}_{3}$ powder. Cross-sectional view of dielectric green sheet. Cross-sectional view of spherical Ni powder. (b) Cross-sectional view of new electrode using $\mathrm{Ni}$ flake powder and $\mathrm{BaTiO}_{3}$ resinate. Cross-sectional view of Ni flake powder. Cross-sectional view of $\mathrm{BaTiO}_{3}$ resinate.

mass $\% \mathrm{BaTiO}_{3}$ was added to $\mathrm{Ni}$ flake powder at an optimal amount, followed by the addition of ethylcellulose (binder) and terpineol (solvent). The resulting mixture was ground to a paste using a simple mixer.

As a paste characteristic of the electrode paste surface roughness, which is a crucial factor for a thin-film electrode, was measured using a surfcom (Tokyo Seimitu). As a sintering characteristic of the electrode paste, firing shrinkage rate was measured as follows. A paste film of approximately 200 $\mu \mathrm{m}$ thickness was formed on a polyethylene terephthalate (PET) film using an applicator and then dried at $100^{\circ} \mathrm{C}$ for 


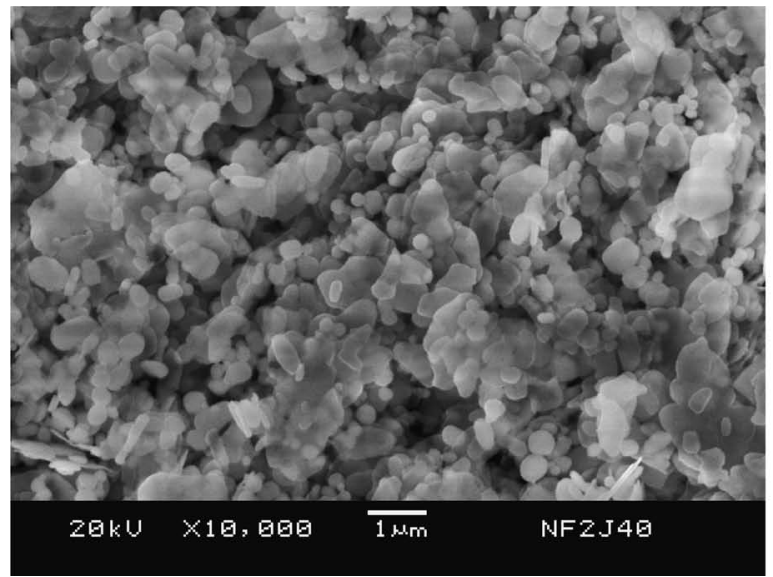

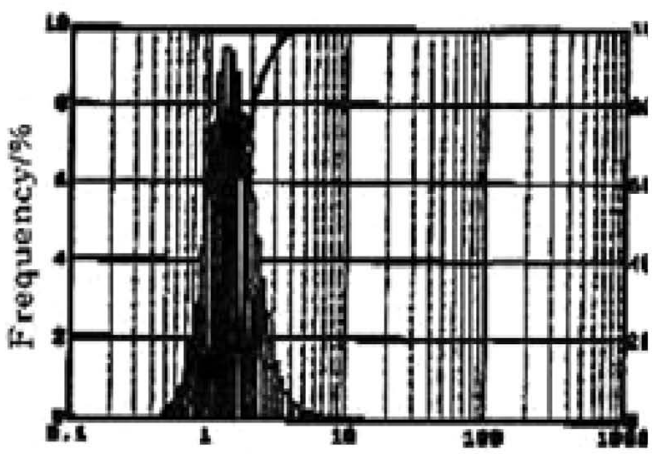

Particle size/ $\mu \mathrm{m}$

Fig. 2. SEM image and particle size distribution of Ni flake powder.

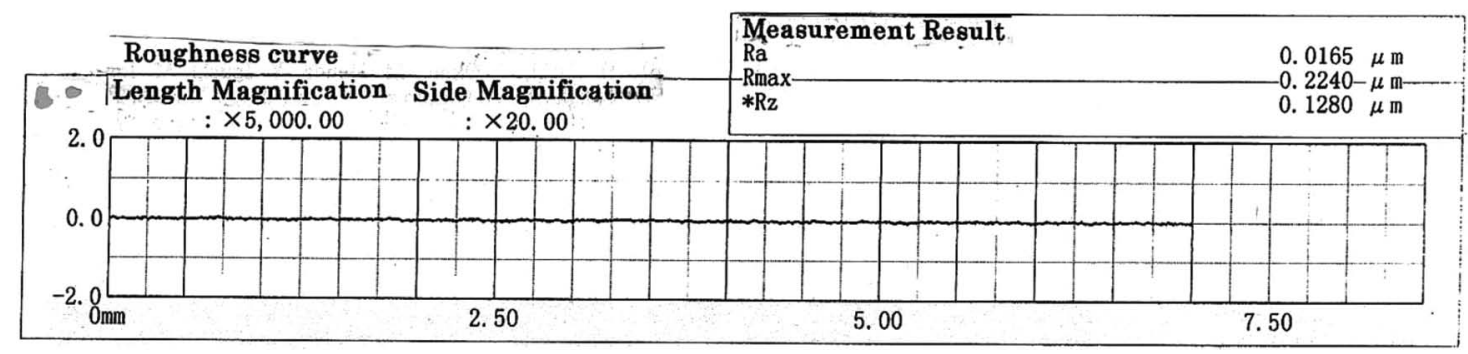

Fig. 3. Surface roughness of Ni paste synthesized using Ni flake powder.

$1 \mathrm{~h}$. The film was peeled off the PET film after drying and cut into 20-mm-diameter disks using a punch. The temperature of each disk was increased at a rate of $3^{\circ} \mathrm{C} / \mathrm{min}$ within the range of $600^{\circ} \mathrm{C}$ to $1200^{\circ} \mathrm{C}$ in a reducing atmosphere of $95 \% \mathrm{~N}_{2}+5 \%$ $\mathrm{H}_{2}$, and the temperature was retained at for $1 \mathrm{~h}$. The dimensions of the disk sample after firing using this temperature program were measured. The maximum firing temperature was set at $1200^{\circ} \mathrm{C}$ because fine particles were used to realize a thinner dielectric layer and a thinner electrode layer, therefore, the firing temperature of the MLCC was decreased. The surface structure of the samples after firing at various firing temperatures was observed using scanning electron microscopy (SEM, JSM-6100, JEOL).

\subsection{MLCC fabrication}

Dielectric paste was prepared from a dielectric with X7R characteristics. MLCCs were obtained from the dielectric paste by the doctor blade method, i.e., a Ni electrode was printed on a dielectric green sheet. This process was repeated 10 times. A green sheet of MLCCs with 10-stacked layers was fired under an applied pressure and cut into $3.2 \times 1.6 \times 2.0$ $\mathrm{mm}^{3}$ (3216 type) chips. The green MLCC chips were degreased by heat treatment at $280^{\circ} \mathrm{C}$ for $8 \mathrm{~h}$ in air and then fired at $1250^{\circ} \mathrm{C}$ for $2 \mathrm{~h}$ in a strongly reducing atmosphere (oxygen partial pressure $\mathrm{PO}_{2}=10^{-13} \mathrm{MPa}$ ). The MLCC chips were heat-treated at $1000^{\circ} \mathrm{C}$ for $3 \mathrm{~h}$ at oxygen partial pressures of $10^{-6}-10^{-7} \mathrm{MPa}$ to reoxidize the dielectrics in the MLCC chips. Oxygen partial pressure was controlled by varying the $\mathrm{H}_{2}$-to- $\mathrm{H}_{2} \mathrm{O}$ ratio of the $\mathrm{N}_{2}-\mathrm{H}_{2}-\mathrm{H}_{2} \mathrm{O}$ gas mixture.

2.3 Evaluation of electrical characteristics of MLCCs

The electrical characteristics of the obtained MLCCs were evaluated as follows: First, a $\mathrm{Cu}$ terminal electrode ( $\mathrm{TCu}-$ 24G, Daiken Chemical Co., Ltd.) was deposited on the exposed surface of the internal electrode. The capacitance $\left(C_{\mathrm{p}}\right)$ and dielectric loss $(\tan \delta)$ of the MLCCs at $1 \mathrm{kHz}$ and $1 \mathrm{~V}$ were measured using an LCR meter (4263B, Agilent Technologies), and the insulation resistance under ac current (50 $\mathrm{V}, 500 \mathrm{~mA}, 30 \mathrm{~s}$ ) was measured using an insulator resistance tester (4339B, Agilent Technologies).

2.4 Preparation of specimen for observation and evaluation of microstructure

The MLCCs were polished in the direction perpendicular to the electrode and dielectric layers so that the microstructures of the electrode and dielectric can be simultaneously observed. The polished sample was observed using a metallurgical microscope to examine the continuity of the electrode and other factors.

\section{Results and discussion}

3.1 Smoothness and sintering characteristics of Ni flake electrode paste

It is important that the surface of the paste deposited by screen-printing be smooth and free of pinholes. Furthermore, for the Ni flake electrode paste used for realizing an ultrathinfilm electrode, coating paste with excellent smoothness is demanded.

Figure 3 shows the measured surface roughness of a $3 \mu \mathrm{m}$ thick dry film formed using the Ni flake electrode paste.

As is evident from the figure, the surface roughness of the Ni flake electrode paste, $R_{\mathrm{a}}$ (the arithmetic average roughness on a roughness curve), and $R_{\max }$ (the maximum roughness on the roughness curve), were $0.03 \mu \mathrm{m}$ and $0.35 \mu \mathrm{m}$, respectively, indicating an extremely smooth roughness curve. Therefore, the Ni flake electrode paste satisfied the smoothness necessary for coating a thin-film electrode. This confirms that Ni flake 


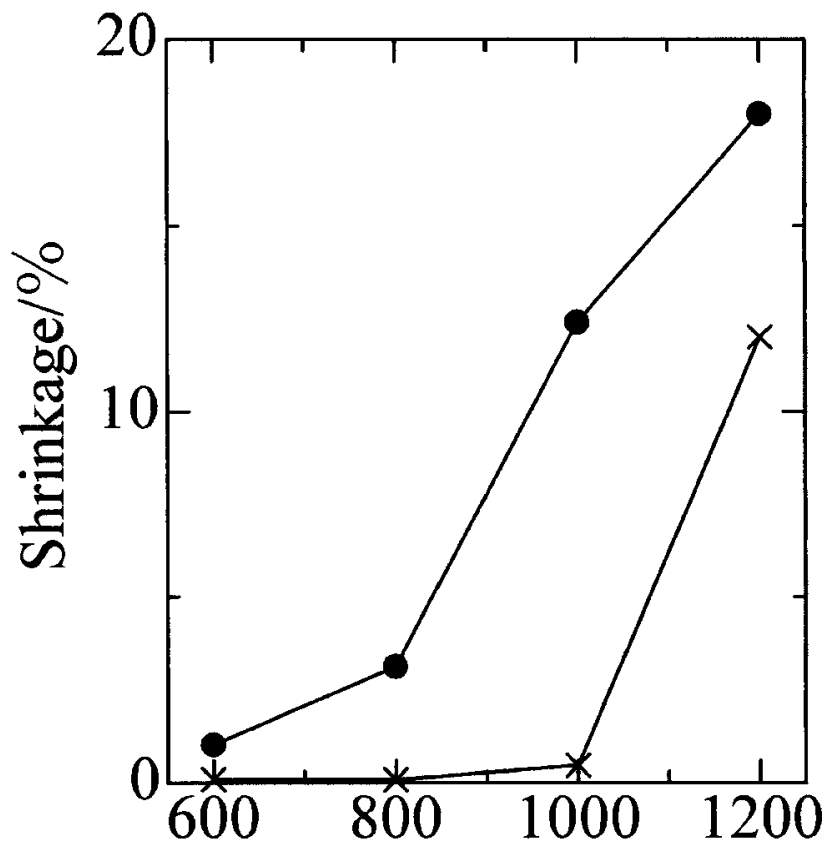

Temperature $/{ }^{\circ} \mathrm{C}$

Fig. 4. Relationship between firing shrinkage rate and firing temperature.

powder can be used as a material for an internal electrode of the MLCCs.

To confirm the sintering shrinkage behavior of the sample prepared using $\mathrm{Ni}$ flake powder, the firing shrinkage rate within a temperature range of $600^{\circ} \mathrm{C}$ to $1200^{\circ} \mathrm{C}$ was measured. Figure 4 shows the result. As is evident from the figure, the sintering of the $\mathrm{Ni}$ flake electrode paste was sufficiently suppressed in the low-temperature region of interest despite initial concerns, and the Ni flake electrode paste had a firing shrinkage rate similar to that of the general dielectric green sheet, according to the overall sintering curve. It was clarified that the sintering characteristics approximated from those observed in the production of MLCCs were obtained. Therefore, Ni flake paste is considered to be a very attractive material for an MLCC electrode. The green density of the Ni flake electrode paste was $5.07 \mathrm{~g} / \mathrm{cm}^{3}$, which was $57.29 \%$ of the filling factor; when the closest packing was made into $60.45 \%$, it was $94.77 \%$, which is quite high relative to the filling factor.

Although we were initially concerned that dry density would decrease with the use of $\mathrm{Ni}$ flake powder, it was clarified that the powder filling rate of the Ni flake electrode paste was comparable to that of conventional $0.1 \mu \mathrm{m}$-diameter $\mathrm{Ni}$ spherical powder, using Ni flake powder with fine particles. Because $\mathrm{BaTiO}_{3}$ particles of nanometer size in solution uniformly intercalate between nickel particles, the powder becomes irregular in flake size and filling density increases.

3.2 Observation of microstructure of sintered surface of $\mathrm{Ni}$ flake electrode paste

The change in the microstructure of the sintered Ni flake electrode paste was observed using SEM. Figure 5 shows the microstructure of the sintered surface of the Ni flake electrode paste. According to SEM images of the surface microstructure shown in Fig. 5, no necking of Ni particles was observed at a firing temperature of $600^{\circ} \mathrm{C}$. At $800^{\circ} \mathrm{C}$, a weak growth of $\mathrm{Ni}$ (a) $600^{\circ} \mathrm{C}$

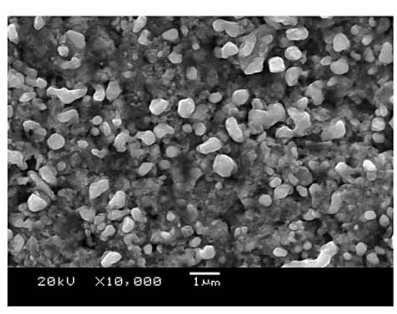

(c) $1000^{\circ} \mathrm{C}$

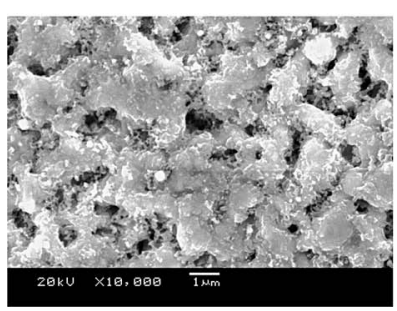

(b) $800^{\circ} \mathrm{C}$

(d) $1200^{\circ} \mathrm{C}$

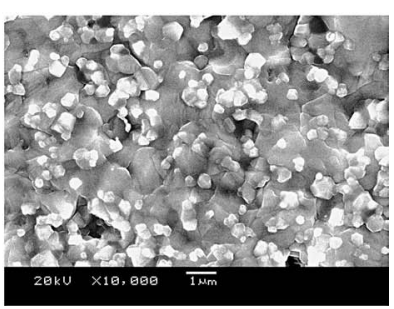

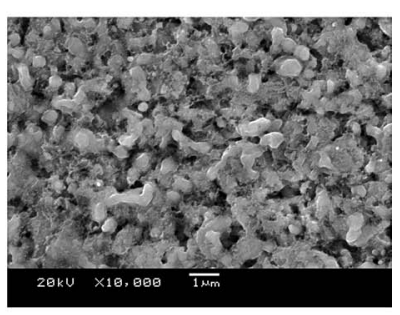

Fig. 5. SEM images of sintered Ni electrode paste prepared from Ni flake powder at various firing temperatures.

particles was observed, and no growth of very large particles was observed. At $1000^{\circ} \mathrm{C}$, a pronounced growth of the sintered particles was observed. When the firing temperature reached $1200^{\circ} \mathrm{C}$, Ni particles were completely sintered. Such a change in the microstructure of the sintered $\mathrm{Ni}$ flake electrode paste indicated the relationship between firing shrinkage rate and firing temperature, as shown in Fig. 4. It is thought that the $\mathrm{BaTiO}_{3}$ resinate was homogeneously dispersed nickel particles in the paste from the result of Figs. 4 and 5, and that sintering controlled at a low temperature.

In this study, we first observed the sintering conditions of Ni paste fabricated using Ni flake powder, from the viewpoint of its microstructure.

3.3 Electrical characteristics of MLCC prepared using Ni flake powder and observation of its microstructure

An MLCC was experimentally fabricated using Ni flake electrode paste as an internal electrode.

The condition of a discontinuous electrode in the MLCC was observed using a metallurgical microscope. Figure 6 shows the results. As observed from the figure, when Ni flake powder no electrode discontinuity occurred in the MLCC, that is, the electrode continuity was very high. The dielectric film thickness after sintering was about $5 \mu \mathrm{m}$, and $\mathrm{Ni}$ electrode film thickness was about $0.9 \mu \mathrm{m}$.

To evaluate the electrical characteristics, capacitance $\left(C_{\mathrm{p}}\right)$, dielectric loss $(\tan \delta)$ and insulation resistance were measured and found to be $45.07 \mathrm{nF}$ (average), $1.47 \%$ and $8.0 \times 10^{9} \Omega$, respectively. The electric capacity expected in our design was clearly $99.5 \%$ from this result.

The above results indicate that the use of $\mathrm{Ni}$ flake electrode paste as an internal electrode of the MLCC enables a thin film to be formed and that the paste has no significant effects on the electrical characteristics of the MLCC.

\section{Conclusions}

Aiming at obtaining an ultrathin electrode film layer using Ni flake electrode paste, the paste characteristics, particularly, 

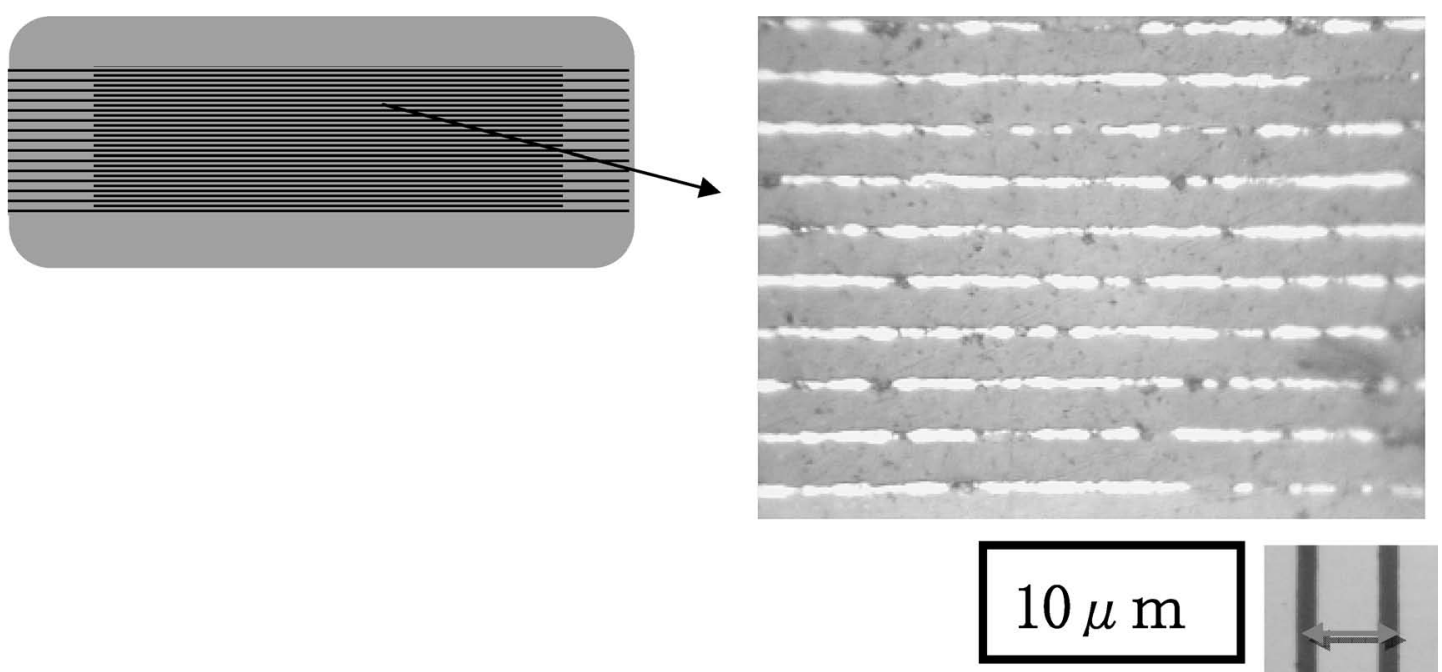

Fig. 6. Cross-sectional view of MLCCs observed using metallurgical microscope.

the effectiveness of this paste as an actual MLCC internal electrode, were examined. The following are our findings.

(1) We evaluated the use of Ni flake powder as a nextgeneration thin-film electrode material, and found that $\mathrm{Ni}$ flake electrode paste has excellent smoothness, is effective for fabricating thin-film electrodes and has excellent sintering characteristics.

(2) By actually fabricating an MLCC, the Ni flake electrode paste was found to be sufficiently useful as a material of the internal electrode of an MLCC.
(3) It was found that $\mathrm{Ni}$ flake powder is very attractive and is highly practical for forming an ultrathin-film $\mathrm{Ni}$ electrode.

\section{References}

1) Ueyama, R., Kuribayashi, K. and Koumoto, K., J. Ceram. Soc. Japan, Vol. 112, pp. 458-461 (2004).

2) Ueyama, R., Kuribayashi, K. and Koumoto, K., Trans. Mater. Res. Soc. of Japan, Vol. 30, pp. 921-924 (2005). 